\title{
Tourism Well-Being and Transitioning Island Destinations for Sustainable Development
}

\author{
Jerome Agrusa ${ }^{1, *}$, Cathrine Linnes ${ }^{2}$, Joseph Lema ${ }^{3}$, Jihye (Ellie) Min ${ }^{4}\left(\right.$, Tony Henthorne ${ }^{3}$, Holly Itoga ${ }^{5}$ \\ and Harold Lee ${ }^{4}$ \\ 1 School of Travel Industry Management, Shidler College of Business, University of Hawaii at Manoa, \\ 2560 Campus Rd., George Hall 346, Honolulu, HI 96822, USA \\ 2 Faculty of Computer Sciences, Østfold University College, BRA Veien 4, 1757 Halden, Norway; cathl@hiof.no \\ 3 Harrah College of Hospitality, University of Nevada Las Vegas, 4505 S. Maryland Pkwy., \\ Las Vegas, NV 89154, USA; joseph.lema@unlv.edu (J.L.); tony.henthorne@unlv.edu (T.H.) \\ 4 College of Merchandising, Hospitality and Tourism, University of North Texas, Chilton Hall 331, \\ 410 S Avenue C, Denton, TX 76201, USA; jihye.min@unt.edu (J.M.); harold.lee@unt.edu (H.L.) \\ 5 Hospitality and Tourism, Business Administration, University of Hawaii-West Oahu, 91-1001 Farrington \\ Highway, Kapolei, HI 96707, USA; holly7@hawaii.edu \\ * Correspondence: jagrusa@hawaii.edu
}

check for updates

Citation: Agrusa, Jerome, Cathrine Linnes, Joseph Lema, Jihye (Ellie)

Min, Tony Henthorne, Holly Itoga, and Harold Lee. 2021. Tourism Well-Being and Transitioning Island Destinations for Sustainable Development. Journal of Risk and Financial Management 14: 32 https://doi.org/10.3390/jrfm14010032

Received: 16 December 2020

Accepted: 8 January 2021

Published: 12 January 2021

Publisher's Note: MDPI stays neutral with regard to jurisdictional clai$\mathrm{ms}$ in published maps and institutional affiliations.

Copyright: $(2021$ by the authors. Licensee MDPI, Basel, Switzerland. This article is an open access article distributed under the terms and conditions of the Creative Commons Attribution (CC BY) license (https:// creativecommons.org/licenses/by/ $4.0 /)$.

\begin{abstract}
The unprecedented growth of tourism over the last century has led to increasing concerns over the sustainable development of many popular tourism destinations throughout the globe. High concentrations of tourists and residents, especially in urbanized areas, have heightened this concern with the arrival of the novel coronavirus (COVID-19) pandemic. Over reliance on tourism has left residents vulnerable to external factors, such as the coronavirus pandemic that has halted tourists from coming to this remote destination. As a result, Hawaii's overall economy is suffering greatly. A survey was developed and distributed to potential tourists in order to acquire their perceptions regarding tourism and well-being, as well as the COVID-19 outbreak. The focus of this study was to examine practices in tourism that moves beyond solely economics which will allow repositioning in a manner that promotes the well-being of both residents and tourists and to transition this unique tourism destination for sustainable development practices for the future. One of the results from the study reported that the majority of the respondents agreed or strongly agreed that testing for COVID-19 should be a travel requirement prior to flying to Hawaii, as well as having an additional COVID-19 test administered upon arrival.
\end{abstract}

Keywords: COVID-19; island tourism; sustainable development; well-being; community impact

\section{Introduction}

The United States' own island paradise, Hawaii, has relied on tourism for its economic survival and sustainability for decades. The tourism arrivals to Hawaii are continuously rising - there was a record number of over 10 million tourist arrivals in 2019. According to the Hawaii Tourism Authority 2019 Annual Visitor Report to the Hawaii State Legislature, Hawaii welcomed over 10 million tourists $(10,451,285)$ for the first time in 2019 , had an increase of 5.7\% $(9,888,845)$ from the previous year (Hawaii Tourism Authority 2019). In a 2018 report, Hawaii's $\$ 14$ billion tourism industry accounted for 21\% of the state's economy, making it one of the largest industries among all the islands (Hawaii Tourism Authority 2018). In 2019, Hawaii received over 10 million tourists with just over one million residents. According to the Hawaii Tourism Authority Resident Sentiment Survey 2019 Highlights Report, the resident sentiment towards tourism has generally weakened, meaning that there is an unequal balance of economic/social and cultural/community benefits from the tourism industry in Hawaii (Hawaii Tourism Authority 2019). Overcrowding in Hawaii is a major factor that affects the local community's views on tourism within a destination along with 
degradation of green areas particularly in high density urban areas. The University of Hawaii Economic Research Organization (UHERO) found that the overall contribution of tourism in the state of Hawaii was greater in 1989 with 6.5 million tourists compared to that the 9.3 million tourists in 2017 (UHERO 2019).

Economic activity produced by visitors to Hawaii exceeded agricultural and military economic activities starting around 1986. Oahu, the most visited island in the state of Hawaii, generates $\$ 7.7$ billion of the overall tourism dollars, with Maui generating the second highest amount of tourism dollars with $\$ 3.5$ billion (Hawaii Tourism Authority 2020). For years, Hawaii has depended on the tourism industry as the leading employer as well as the economic engine and its main source of income for Hawaii's economy (Agrusa 1994; Linnes et al. 2014). The tourism industry accounted for over 150,000 employment opportunities for the state of Hawaii in 2017 (Department of Business and Economic Development and Tourism 2018). Spending by tourists accounted for over $\$ 16.64$ billion in 2017 alone (Hawaii Tourism Authority 2017). According to an article in the Washington Post stated that tourism accounted for a $21 \%$ direct contribution to the entire state of Hawaii's GDP (Wilson 2017).

Although tourism to Hawaii had been exploding for the past 10 plus years, the impact of the coronavirus pandemic demonstrated that tourism could be a major economic weakness due to the fact that Hawaii should not be dependent on only one industry for their economy. Occupancy rates in Hawaii's hotels from March 2020 onwards collapsed at a deafening rate and nearly dropped $99 \%$ (Hawaii Tourism Authority 2020) while continuing in a concerning downward direction.

This study is considered timely since the outbreak of the COVID-19 pandemic has virtually stopped tourism to many remote island destinations. For this study, the use of a literature-based research methodology was implemented in which the literature review is a methodology in its own right or as the main contribution for the study (Kitchenham 2004). While limited, there have been a number of tourism disaster research studies whether natural disasters such as earthquakes or tsunami's or human induced disasters such as terrorism (Faulkner and Vikulov 2001; Min et al. 2020a; Morrison and O'Leary 1994; Rittichainuwat 2013; Rittichainuwat et al. 2018; Rosenbaum and Spears 2005). This study focuses on the effects of COVID-19, the well-being of tourists and residents, along with the sustainable development of tourism destinations. Furthermore, the study aims to identify possible solutions for improving the sustainability of tourism from an economic perspective in addition to beyond economics to benefit the residents' well-being and the unique natural environment of the destination.

Reliance on one industry leaves any location vulnerable to external factors (Min et al. 2020b), such as the COVID-19 pandemic, which has halted tourists from coming to Hawaii. As a result, Hawaii's overall economy is suffering greatly (Hawaii Tourism Authority 2020). However, the COVID-19 pandemic can have a silver lining, allowing Hawaii's tourism to reset or reposition itself within the realm of more sustainable development including green economics, to attract the number as well as the types of tourists that will benefit the local community, and the sustainability of the natural environment. The structure of the paper following the preliminary introduction includes the research background; literature review; methodology; results and discussion; and conclusion.

\section{Research Background}

Overcrowding is a factor that affects the local community's views on tourism within a destination. Prior to the COVID-19 pandemic, Hawaii has experienced an overflow of tourists, where tourists are filling up local beaches and are taking up space on the island that is usually reserved for the local population. The over crowdedness may also negatively affect other tourists' experiences when visiting Hawaii, where tourists might decide not to return to visit Hawaii again because of the long lines on hiking trails or lack of space and large crowds at beach parks. In addition, the overflow of tourists has weakened the economy because although the number of visitors is high, visitor expenditures are far too low. A 2018 report 
by the Economic Research Organization of the University of Hawaii found that the overall contribution of tourism in the state of Hawaii was greater in 1989 with 6.5 million tourists compared to that the 9.3 million tourists in 2017 (UHERO 2019). In an article by Mia Taylor (2019) a reporter for Travel Pulse, found that when investigating the sustainability of Hawaii's tourism product there are a number of issues and challenges that have to be addressed in moving forward. These challenges reported by Taylor (2019) include:

"The economic contributions of tourism have not kept pace with explosive growth in visitor arrivals. Despite the fact that Hawai'i received 2.8 million more visitors in 2017 than in 1989, real (inflation adjusted) receipts were $\$ 1.1$ billion less in 2017 than in 1989. Real expenditures in 2017 peaked at $\$ 17.9$ billion in 1989 and then fell and rose with economic cycles, but likely still fell short of the peak again in 2018. The long-term decline in overall (real) visitor spending is largely due to the sharp decline in spending per visitor per day. Another way to look at economic impact is to measure real visitor spending per resident. This measure has declined from $\$ 17,195$ (2017 dollars) in 1989 to $\$ 11,752$ in 2017" (p. 2).

An example of a major challenge for the hospitality industry and the well-being of its residents has been the introduction of short-term vacation rentals (STRs) on platforms such as Airbnb, which have brought some disadvantages to tourist destinations and Hawaii as an island destination has not been immune to the effects of this new accommodation. Peer-to-peer consumption or the sharing economy are some of the names that refer to this new type of lodging (Langley and Leyshon 2017).

Airbnb and other online platforms have proliferated, which rent out apartments as well as whole homes in residential areas, which has resulted in an enormous impact on the local residents as well as the destination areas itself that attract the tourists (Harris 2018). The costs and benefits of these new informal accommodations on destinations, especially tourist locations, must be fully analyzed and then decide how to address the positive and negative effects on the community as well as the stakeholders at these destinations. Arguably acknowledged as economic disrupters, short term vacation rentals by their nature transcends economics to also complicate policymaking and legislation (Biber et al. 2017). The incredible growth of STRs is proving to be a tremendous challenge for legislators and local authorities on how to regulate or to not regulate this new form of accommodations (Hajibaba and Dolnicar 2017). STRs are privately-owned accommodation rental websites that connect travelers with homeowners having vacant apartments, rooms, and homes to rent out. The most famous of all the short-term vacation rental platforms is that of Airbnb, which was founded in 2008, and is headquartered in San Francisco, California (Guttentag 2015).

An investigative report by Hawaii News Now on Airbnb and other illegal vacation rentals shows that 1 in every 24 homes are vacation rentals-about 24,000 homes in the state of Hawaii (Blair 2018). More than half of the STR rental properties in Hawaii are owned by non-residents (Blair 2018). With Hawaii having one of the lowest property tax rates in the United States, real estate speculators are taking advantage and capitalizing on the lack of enforcement in Honolulu on the illegal short-term vacation rentals at the expense of Honolulu residents. It was found that $52 \%$ of the 23,000 Airbnb and other STRs in Hawaii are owned by nonresidents (Geminiani and DeLuca 2018). In Hawaii, given the rising rental rates and the lack of available housing opportunities for residents, Geminiani and DeLuca (2018) argued that the proliferation of Airbnb and other STRs have worsened the resident's housing crisis situation, and concluded, "the current state of vacation rental units in Hawaii is not ... balanced and sustainable" (p. 12). By taking hundreds, or even thousands of rental apartments, as well as whole homes off the market, and having them used as illegal Airbnb's and other short- term vacation rental platforms, has resulted in placing the resident housing rental market of Hawaii in a precarious position.

Hawaii is the most remote highly populated landmass in the world and this isolation has worked in the favor of Hawaii with COVID-19. The state of Hawaii has maintained one of the lowest percentage of residents testing positive for COVID-19, with the majority 
of the residents who did test positive have recently returned from traveling outside the Hawaii Islands (Hawaii Tourism Authority 2020). As an isolated island in the middle of the Pacific Ocean, Hawaii to some extent is naturally self-isolated from the U.S. mainland. This means there are only two ways of arriving to Hawaii: either by plane or by ship. The overwhelming majority of the tourists visiting Hawaii travel by airplane as it is more favorable of the two options because of the much shorter trip duration. Being mainly accessible only by air indicates that Hawaii is highly vulnerable to changes in aviation fuel prices, as well as other challenges that an airline may face, such as terrorism for example what happen after 9/11 and now with the COVID-19 pandemic. Moreover, Hawaii's isolation translates into a significant travel cost for people who want to visit the islands. There is a high monetary cost, as well as a cost of people's time, in traveling to such a remote destination.

Due to the small land mass and isolation of Hawaii, the state has to import a majority of its goods. Almost all of the food available in the islands are shipped in from the U.S. mainland. In the port of Honolulu, one will find a great number of carrier ships that bring approximately six million pounds of food into Hawaii every day, in efforts to feed the population of over one million residents combined with the 10 million annual visitors. In addition, there are a great deal of perishables and other goods that get flown into Hawaii by carrier planes. Hawaii's geographic location causes the state to import approximately $90 \%$ of its food, thus costing Hawaii at least U.S. $\$ 3$ billion (Woody 2015). Food importation is a major weakness especially from a sustainability and financial standpoint because not only is so much money spent on imports, but there is an environmental cost as well. Some of the largest shipping vessels can release as much pollution as 50 million cars annually (Woody 2015). The fact that shipping is responsible for around $4 \%$ of global greenhouse gases emphasizes how much of a carbon footprint Hawaii is making (Woody 2015). Economically, as a result of having to import food from the U.S. mainland this consequently drives up the overall cost of basic amenities and necessities for Hawaii residents. This is especially a weakness when tourists see how expensive everything is due to the mark-up; for some, it might be too expensive overall, and they would decide not to return to Hawaii as future visitors.

\section{Literature Review}

COVID-19 has brought an opportunity for Hawaii to become more sustainable which can help balance between the needs of the local residents and the desire of the tourists resulting in producing a sustainable tourist product. This research paper provides several recommendations for Hawaii's tourism and government officials in order to be a more sustainable and responsible tourism destination. As an established tourism destination Honolulu Hawaii, known as the heart of Hawaii's economic tourism industry, deserves to have regulations that will allow the residents of Hawaii as well as the tourists to enjoy the tourism product in addition to being sustainable.

Opportunities exist for the tourism sector to address the environmental, social, and political terms in the era of COVID-19 (Baum and Hai 2020). With international tourism declining over $70 \%$ in 2020, with a return to levels of 30 years ago, the prospect of a vaccine rollout is desperately required for consumer confidence, easing of travel restrictions, and the recovery of tourism (UNWTO 2020). The economic needs however, along with the immediate stimulus required for recovery, may prevail over longer-term environmental or social obligations (McCartney 2020). In terms of social costs, traditional policy measures may not be sufficient for destinations highly dependent on tourism alone to address the socio-economic challenges of the pandemic (Qiu et al. 2020).

Therefore, residents need have an important contribution in recovery over the short and long-term sustainability initiatives of the Hawaiian Islands. Buckley and Westaway (2020) contend that in the new theoretical paradigm of tourism-nature-health that identified novel outcomes exist from psychological to life and family flow components within community well-being. Furthermore, Bimonte and D'Agostino (2020), argue that the 
development of tourism affects residents' perceived well-being on both individual and community levels. Sustainability initiatives will need to maintain a front and center approach amidst the pandemic and communicated throughout the wide range of stakeholders that exists within the complexity of tourism and related entities.

Networking structures such as the Local Agenda 21 (LA21) implemented in the case of the Balearic Islands of Spain, successfully integrated a clustered stakeholder approach to sustainable tourism development with a particular focus on local community participation and involvement (Barrutia and Echebarria 2015). The participation among multiple stakeholders allowed for a shared approach to the costs and benefits that was more easily understood through the collaborative network. Similarly, in the case of Jeju Island, a major nature-based destination in South Korea, tourists' perceptions of sustainability were examined to determine that visitor perception was more heavily influenced by communicating sustainability needs before and during the tourist visitation rather than trying to educate after the trip (Kim et al. 2017). Furthermore, in the case of Jamaica, transparency in tourist user fees was paramount to build community trust in regards to fee allocation and in what aspects in the preservation or sustainability of the natural attraction (Edwards 2009). Imposing a user fee coupled with educational and learning opportunities has also been observed as a successful approach to sustainability in a number of other cases among both tourists and residents perspectives (Ballantyne and Packer 2011; Herremans 2006; Lema et al. 2010; Tanner et al. 2004).

One approach to assist the state of Hawaii in becoming a more sustainable destination would be to implement a charge or fee for visitors to enter state parks and hiking trails that supports preservation of the natural environment. A promising success story of sustainability in Hawaii is that of the Hanauma Bay Nature Preserve, which was deteriorating under the weight of over 7500 tourists per day in the late 1980s. In 1990, the city and county of Honolulu laid out a plan to restore Hanauma Bay to a clean, healthy state by reducing the number of visitors, establishing an education program and instituted supportive restrictions in highly vulnerable natural habitats. By limiting the parking spaces to 300, and not allowing tour buses to drop off passengers, and charging tourist $\$ 7.50$ entrance fee as well as allowing Hawaii residents to enter at no cost, Hanauma Bay has been able to bring itself back to become an environmentally sustainable destination as well as a more environmental friendly location for residents to enjoy. The promotion of green preferences among visitors and residents coupled with crowd aversion provides a pathway for green tourism development (Loria and Lee 2018). In the era of COVD-19 crowd aversion is essential for maintaining social distancing and safety for both residents and tourists.

Previous research has established that there is a willingness for tourists to pay for access to natural attractions and the state of Hawaii can capitalize on the tourist's commitment to pay for access (Park et al. 2006; Ritchie 2004). In addition, studies have found that the user, tourists of natural attractions, support paying acceptable fees, and expect that the attractions are kept up to an acceptable standard with clean rest rooms, clean trails, and a secured parking area (Reisinger and Turner 2002; Ritchie 2004). Hawaii's government and tourist officials should consider charging visitors for access to the natural attractions such as imposing a \$25 fee to hike Diamond Head trail or Koko Head crater and allow Hawaii's residents free admission. The fees collected from the tourists can be used for the preservation and conservation of the attraction as well as enabling Hawaii resident's greater access to these attractions that will help improve Hawaii residents' sentiment in reference to tourism and improving residents' perceptions that not everything the government of Hawaii does is only for the tourists.

\section{Method}

A survey was developed and distributed to a targeted population on their perceptions regarding tourism to Hawaii and the COVID-19 outbreak. The questionnaire consisted of a selection of items to represent the attributes and challenges that tourists are facing in traveling to and visiting Hawaii during the COVID-19 outbreak based on an extensive 
review of the literature. For this study, 26 items, which included demographic items, such as age, gender, marital status, and location of origin, as well as ethnicity, were used to measure attitudinal or behavioral characteristics of United States residents traveling to Hawaii during the COVID-19 outbreak. The items were selected from tourists' motivation, attitude, or behavior items previously used in the international travel literature (Jang and Cai 2002; Kim et al. 2003; Kim and Prideaux 2005; Jang et al. 2004; Kozak 2002; McKercher and Wong 2004; Taylor 2019; Wilson 2017). The items were adapted to describe travel to Hawaii during the COVID-19 pandemic. Responses to the items were measured on a 5point Likert-type scales where 1 = 'strongly disagree,' 3 = 'neutral,' and 5 = 'strongly agree.'

Categorical data consisted of specific purposes of confidence of traveling on an airplane during the COVID-19 outbreak, being comfortable sitting next to someone on the airplane, comfortable having a COVID-19 test taken prior to traveling to Hawaii as well as questions on Hawaii's 14-day quarantine for travelers visiting Hawaii and the penalties for violations of the 14-day hotel room quarantine. Hawaii tourism-related items were also included which originated from a review of previous studies (Agrusa 1998; Agrusa 2000; Lee and Jinlin 2003; Mistilis and Sheldon 2005; Morrison and O'Leary 1994; Reynisdottir et al. 2008; Ritchie 2004; Shoemaker 1994). The objective of the research questionnaire was to attain the attitudinal or behavior characteristics of U.S. residents visiting Hawaii during the COVID-19 outbreak. The questionnaires were available to the respondents in English.

To avoid ambiguity in the questions, and to ensure that all of the questions written on the survey instrument were clearly understood, a pilot test of 20 U.S. tourists who have traveled to Hawaii was completed prior to data collection. Participation in this study was voluntary and respondents were ensured of the absolute confidentiality of their answers to all questionnaire items. Due to the survey being anonymous and self-administered, it is believed that all respondents answered the survey instrument honestly. In order to assess the differences of characteristics, such as comfort of flying during COVID-19, comfort of wearing a facemask during their flight, image of Hawaii as a safe destination during the COVID-19 pandemic, as well as how likely will you be planning a trip to Hawaii within the next year, according to age group, a correspondence analysis was undertaken.

\section{Data Collection}

The sample for this study was recruited through Qualtrics, which is an online survey company. Qualtrics is an experience management company that is well known for online consumer research (Qualtrics). Furthermore, Qualtrics can be used to obtain more diverse samples compared to those from face-to-face or other online and social media platforms (Brunt et al. 2017). Since the outbreak of the coronavirus pandemic, face-to-face survey data collection is strongly discouraged. According to Molnar (2019), Qualtrics has become very popular among researchers in academia who design non-interactive online experiments and has several advantages over platforms, specifically designed for experiments and is completely web-based and offers a more intuitive and streamlined interface (Morrison and O'Leary 1994). For the study, the participants were randomly recruited from the company's online research panel. The survey contained two screening questions: the participants were asked (1) if they are 18 years or older, and (2) if they have traveled on an airplane for vacation at least once in the last year. As a result, 371 useable surveys (of the original 896) were retained after screening for unqualified, incomplete, invalid (i.e., showed contradictions in answering cross-validation items) and disingenuous (i.e., answered all questions the same) responses. This study explores the following two research questions:

- RQ1: what measures support visitor and resident well-being when seeking a remote island vacation destination?

- RQ2: will proactive COVID-19 measures have a positive impact on the island destination? 


\section{Results and Discussion}

\subsection{Demographic Statistics}

The first part of the results presents this initial portion of the questionnaire; hence, the demographic characteristics of the survey respondents measured using ordinal scale variable are illustrated in Table 1. The data are reported in percentage and frequency.

Table 1. Demographic characteristics of the respondents $(n=370)$.

\begin{tabular}{|c|c|c|c|}
\hline Profile & Options & Frequency & Percentage \\
\hline \multirow[t]{5}{*}{ Age } & $>55$ & 6 & $1.6 \%$ \\
\hline & $45-55$ & 88 & $23.8 \%$ \\
\hline & $35-44$ & 117 & $31.6 \%$ \\
\hline & $25-34$ & 117 & $31.6 \%$ \\
\hline & $<25$ & 42 & $11.4 \%$ \\
\hline \multirow[t]{3}{*}{ Gender } & Male & 177 & $47.8 \%$ \\
\hline & Female & 190 & $51.4 \%$ \\
\hline & Other & 3 & $0.8 \%$ \\
\hline \multirow[t]{6}{*}{ Ethnicity } & White & 240 & $64.9 \%$ \\
\hline & Black or African American & 43 & $11.6 \%$ \\
\hline & Spanish, Hispanic, or Latino & 1 & $0.3 \%$ \\
\hline & American Indian or Alaska Native & 21 & $5.7 \%$ \\
\hline & Native Hawaiian or Pacific Islander & 4 & $1.1 \%$ \\
\hline & Other & 61 & $16.5 \%$ \\
\hline \multirow[t]{5}{*}{ Marital status } & Single & 136 & $36.8 \%$ \\
\hline & Married & 177 & $47.8 \%$ \\
\hline & Widowed & 12 & $3.2 \%$ \\
\hline & Divorced & 39 & $10.5 \%$ \\
\hline & Separated & 6 & $1.6 \%$ \\
\hline \multirow[t]{4}{*}{ Region } & Northeast & 70 & $18.9 \%$ \\
\hline & Midwest & 76 & $20.5 \%$ \\
\hline & South & 139 & $37.6 \%$ \\
\hline & West & 85 & $23.0 \%$ \\
\hline
\end{tabular}

Note: maturist $=>55$; baby boomers $=45-55$; generation $\mathrm{x}=35-44$; generation $\mathrm{y}=25-35$; generation $\mathrm{z}=<25$.

\subsection{Descriptive Analysis}

The descriptive analysis includes the values shown in Table 2 for minimum, maximum, mean, standard deviation, skewness, and kurtosis. SPSS were used to calculate the values. The mean value is found to be above 2.5 based on a 5 -point scale. Where the majority of the respondents were between 35 and 44 years of age. The standard deviation indicates a small intermediate distribution between the mean showing that the respondents agree. The data were evaluated for normality and found to be within $+/-1.00$ and normally distributed. The value for gender, ethnicity, and region were found to be flatter than normal and the value for marital status peakier than normal.

Table 2. Descriptive analysis-pertaining to flying.

\begin{tabular}{ccccccc}
\hline Profile & Min & Max & Mean & SD & Skewness & Kurtosis \\
\hline Age & 1 & 5 & 3.27 & 1.001 & 0.019 & -0.831 \\
Gender & 1 & 3 & 1.53 & 0.516 & 0.127 & -1.575 \\
Marital status & 1 & 5 & 1.92 & 1.240 & 0.127 & 1.051 \\
Ethnicity & 1 & 4 & 2.65 & 1.034 & 0.127 & -1.062 \\
Region & 1 & 6 & 2.23 & 2.167 & 0.127 & -1.183 \\
\hline
\end{tabular}

The participants clearly recommended summertime as the number one choice for traveling to Hawaii $33.8 \%$, followed by spring $26.9 \%$, winter $25.7 \%$, and fall $13.6 \%$. For this question, 40 participants left the question blank. In terms of working in the tourism 
or hospitality industry, $22.6 \%$ reported working in this field, while $77.4 \%$ reported not working in either of these fields. Regarding living close near a major tourism area, a slight majority $188(50.8 \%)$ participants reported yes-that they did live near a tourist area and $182(49.2 \%)$ reported no, they did not live near a tourist area. In terms of frequency of traveling, a majority of the respondents $121(32.7 \%)$ answering the survey indicated that they took 2-3 trips last year on an airplane, followed by $68(8.4 \%)$ of the respondents who traveled at least once, with 30 or $(8.1 \%)$ of the respondents stating they took $4-5$ trips by airplane last year, and 17 (4.6\%) of the respondents took more than 5 trips, while 134 (36.2\%) of the respondents stated they did not travel on an airplane last year. This question was asked to ensure that the study receives respondents who are considered frequent travelers and most likely to be travelers who would visit Hawaii.

\subsection{ANOVA}

Table 3 displays the participants' feelings regarding traveling and getting on board an aircraft after the COVID-19 outbreak. The question of most interest was the one asking about reconfiguring the aircrafts to only hold business/first class seats to allow more room and social distancing between all seats in all directions even if the ticket price increased. There was a significant difference p.012 < 0.05 (SE.422). One can clearly see that Generation $X$ (3.50) and Generation Y (3.54) clearly agree with this statement. These are also the two groups (Gen X and Gen Y) that are most financially stable and are most likely to travel the most, along with demonstrating a willingness to pay for safety and comfort. The results of this question should be a wakeup call for airlines to start reconfiguring their aircrafts, as not everyone is willing to be packed in a highly congested and contained aircraft especially during the COVID-19 pandemic.

The question asking if the participants feel comfortable flying on an airplane, and if they will take a trip that will include flying on an airplane over the next 12 months indicated there were also a significant difference p.012 < 0.05 (SE.333). Only the maturists strongly disagreed that they felt comfortable in flying in an airplane over the next 12 months, while the other generations were neutral to this statement. However, to be able to change the traveler's opinions, to make them feel comfortable to fly on an airplane, the airline companies need to be proactive and make changes to the configuration of the seats for social distancing, and changes to its operations, such as disinfecting the aircraft, and implementing new and improved air filtering systems on the airplane.

In terms of being comfortable having their temperature taken before flying, there were a significant difference p.001 < 0.05 (SE.563). The baby boomer generation, born between 1945 and 1964, strongly agreed that they were comfortable having their temperature taken before flying, the maturists, Generation $X$ and $Y$ agreed with this statement, while Generation $\mathrm{Z}$ were neutral with this statement.

For the question in reference to the comfort level of having a COVID-19 test taken before flying on an airplane, there was a significant difference p.039<0.05 (SE.061). The baby boomers, Generation X, and Generation Y indicated they agreed they felt comfortable taking a COVID-19 test before flying on an airplane. However, Generation Z, and maturists were neutral. One question inquired if a person felt comfortable with airline employees wearing facemasks onboard and a significant difference was found p.014< 0.05 (SE.055). Maturists, Generation Y, and Generation Z agreed with the statement, while baby boomers, along with Generation $X$ strongly agreed.

For the questions particularly pertaining to Hawaii as a sustainable tourism destination, there were some obvious differences see Table 4. Some people believe that having the 14-day quarantine for visitors to Hawaii can avoid Hawaii becoming a 'hot zone' for the virus and will increase Hawaii's 'image as a safe destination' do you agree with this statement, there was a significant difference p.036 < 0.05 (SE.060). The maturists disagreed, generation $\mathrm{z}$ was neutral, while the baby boomers, Generation X, and Generation Y all agreed with Hawaii being looked upon as a safe destination by imposing such measures. As tourists have a large number of vacation destinations to choose from, and if a tourist feels 
unsafe at a destination, they might end up selecting an alternative destination where they feel safe or taking other forms of transportation to a destination that is considered safer.

Table 3. Questions pertaining to flying.

\begin{tabular}{|c|c|c|c|c|c|c|}
\hline \multicolumn{7}{|c|}{ ANOVA } \\
\hline & & $\begin{array}{l}\text { Sum of } \\
\text { Squares }\end{array}$ & df & Mean Square & $\mathbf{F}$ & Sig. \\
\hline \multirow{3}{*}{ I feel confident that it is safe to fly on an airplane. } & Between Groups & 16.152 & 4 & 4.038 & 2.234 & 0.065 \\
\hline & Within Groups & 659.859 & 365 & 1.808 & & \\
\hline & Total & 676.011 & 369 & & & \\
\hline \multirow{3}{*}{$\begin{array}{l}\text { Over the next } 12 \text { months I feel comfortable that I } \\
\text { will take a trip that will include flying on } \\
\text { an airplane. }\end{array}$} & Between Groups & 24.165 & 4 & 6.041 & 3.287 & 0.012 \\
\hline & Within Groups & 670.754 & 365 & 1.838 & & \\
\hline & Total & 694.919 & 369 & & & \\
\hline \multirow{3}{*}{$\begin{array}{l}\text { I am comfortable having my temperature taken } \\
\text { before flying on an airplane. }\end{array}$} & Between Groups & 21.707 & 4 & 5.427 & 4.793 & 0.001 \\
\hline & Within Groups & 413.269 & 365 & 1.132 & & \\
\hline & Total & 434.976 & 369 & & & \\
\hline \multirow{3}{*}{$\begin{array}{l}\text { I feel comfortable sitting directly next to someone } \\
\text { (not a family member) on an airplane. }\end{array}$} & Between Groups & 8.926 & 4 & 2.232 & 1.245 & 0.291 \\
\hline & Within Groups & 654.071 & 365 & 1.792 & & \\
\hline & Total & 662.997 & 369 & & & \\
\hline \multirow{3}{*}{$\begin{array}{l}\text { I feel comfortable about wearing a facemask on } \\
\text { an airplane. }\end{array}$} & Between Groups & 11.789 & 4 & 2.947 & 2.052 & 0.087 \\
\hline & Within Groups & 524.343 & 365 & 1.437 & & \\
\hline & Total & 536.132 & 369 & & & \\
\hline \multirow{3}{*}{$\begin{array}{l}\text { I feel comfortable with airline employees } \\
\text { wearing facemasks on your flight. }\end{array}$} & Between Groups & 13.618 & 4 & 3.404 & 3.168 & 0.014 \\
\hline & Within Groups & 392.209 & 365 & 1.075 & & \\
\hline & Total & 405.827 & 369 & & & \\
\hline \multirow{3}{*}{$\begin{array}{l}\text { I feel comfortable eating the food served on the } \\
\text { airplane? }\end{array}$} & Between Groups & 3.328 & 4 & 0.832 & 0.643 & 0.632 \\
\hline & Within Groups & 472.253 & 365 & 1.294 & & \\
\hline & Total & 475.581 & 369 & & & \\
\hline \multirow{3}{*}{$\begin{array}{l}\text { I believe the aircraft should be reconfigured to } \\
\text { only hold business / first class seats to allow more } \\
\text { room between all seats in all directions even if } \\
\text { the ticket price increases. }\end{array}$} & Between Groups & 15.794 & 4 & 3.949 & 3.259 & 0.012 \\
\hline & Within Groups & 442.217 & 365 & 1.212 & & \\
\hline & Total & 458.011 & 369 & & & \\
\hline \multirow{3}{*}{$\begin{array}{l}\text { I feel confident that the airline will securely } \\
\text { protect my personal information. }\end{array}$} & Between Groups & 3.972 & 4 & 0.993 & 0.868 & 0.483 \\
\hline & Within Groups & 417.747 & 365 & 1.145 & & \\
\hline & Total & 421.719 & 369 & & & \\
\hline \multirow{3}{*}{$\begin{array}{l}\text { I am comfortable having a COVID-19 test taken } \\
\text { before flying on an airplane. }\end{array}$} & Between Groups & 13.815 & 4 & 3.454 & 2.550 & 0.039 \\
\hline & Within Groups & 494.296 & 365 & 1.354 & & \\
\hline & Total & 508.111 & 369 & & & \\
\hline \multirow{5}{*}{$\begin{array}{l}\text { I am comfortable having a COVID-19 test taken } \\
\text { after I arrive in the destination. }\end{array}$} & Between Groups & 13.832 & 4 & 3.458 & 2.324 & 0.056 \\
\hline & Within Groups & 543.195 & 365 & 1.488 & & \\
\hline & Total & 557.027 & 369 & & & \\
\hline & Within Groups & 597.322 & 365 & 1.636 & & \\
\hline & Total & 614.000 & 369 & & & \\
\hline
\end{tabular}

Note: $\mathrm{df}=$ degree of freedom, $\mathrm{F}$ = f-test, sig = significant value.

In terms of Hawaii having a 14-day quarantine to stop the spread of coronavirus, there was a significant difference p. $039<0.05$ (SE.067). The maturists disagreed that the 14-day quarantine would stop the spread of the coronavirus while Generation $X$ and $Y$ slightly agreed with this statement. The other generations, however, responded neutral to this statement.

The question in reference to a tourist who violates the 14-day quarantine in Hawaii, and leaves their hotel room or vacation rental prior to the completion of the 14-day quarantine can be arrested, and have to serve one year in jail-there was a significant difference p.001 0.05 (SE.070). The maturists and baby boomers disagreed with this statement while 
Generation Y slightly agreed that violating the 14-day quarantine in Hawaii, and leaving their hotel room or vacation rental prior to the 14 days, can be arrested and have to serve one year in jail, while the other generations answered neutral.

Table 4. Questions pertaining to Hawaii as a tourist destination.

\begin{tabular}{|c|c|c|c|c|c|c|}
\hline \multicolumn{7}{|c|}{ ANOVA } \\
\hline & & $\begin{array}{l}\text { Sum of } \\
\text { Squares }\end{array}$ & df & $\begin{array}{c}\text { Mean } \\
\text { Square }\end{array}$ & $\mathbf{F}$ & Sig. \\
\hline \multirow{3}{*}{$\begin{array}{l}\text { Some destinations such as Hawaii have a 14-day } \\
\text { quarantine for travelers visiting these destination to stop } \\
\text { the spread of coronavirus, do you agree with } \\
\text { this quarantine. }\end{array}$} & Between Groups & 11.357 & 4 & 2.839 & 1.830 & 0.122 \\
\hline & Within Groups & 566.362 & 365 & 1.552 & & \\
\hline & Total & 577.719 & 369 & & & \\
\hline \multirow{3}{*}{$\begin{array}{l}\text { Tourists that violate the rules of the } 14 \text {-day quarantine in } \\
\text { Hawaii and leave their hotel room or vacation rental prior } \\
\text { to the } 14 \text { days can be arrested and serve } 1 \text { year in jail do } \\
\text { you agree with this law. }\end{array}$} & Between Groups & 31.630 & 4 & 7.908 & 4.524 & .001 \\
\hline & Within Groups & 637.981 & 365 & 1.748 & & \\
\hline & Total & 669.611 & 369 & & & \\
\hline \multirow{3}{*}{$\begin{array}{l}\text { Tourists that violate the rules and regulations of the 14-day } \\
\text { quarantine in Hawaii and leave their hotel room or } \\
\text { vacation rental prior to the } 14 \text { days should be fined } \$ 5000 \\
\text { do you agree with this law. }\end{array}$} & Between Groups & 31.595 & 4 & 7.899 & 4.560 & .001 \\
\hline & Within Groups & 632.232 & 365 & 1.732 & & \\
\hline & Total & 663.827 & 369 & & & \\
\hline \multirow{3}{*}{$\begin{array}{l}\text { Hawaii's Governor has extended the 14-day quarantine for } \\
\text { visitors to continue to the end of next month until } 30 \text { June, } \\
\text { do you believe this is necessary. }\end{array}$} & Between Groups & 5.300 & 4 & 1.325 & 0.770 & 0.546 \\
\hline & Within Groups & 628.443 & 365 & 1.722 & & \\
\hline & Total & 633.743 & 369 & & & \\
\hline \multirow{3}{*}{$\begin{array}{l}\text { Some people believe that the 14-day quarantine for } \\
\text { visitors to Hawaii is anti-tourism, do you agree with } \\
\text { this statement. }\end{array}$} & Between Groups & 6.973 & 4 & 1.743 & 1.037 & 0.388 \\
\hline & Within Groups & 613.300 & 365 & 1.680 & & \\
\hline & Total & 620.273 & 369 & & & \\
\hline \multirow{3}{*}{$\begin{array}{l}\text { Some people believe that having the 14-day quarantine for } \\
\text { visitors to Hawaii can avoid Hawaii becoming a 'hot zone' } \\
\text { for the virus and will increase its "Image as a Safe } \\
\text { Destination" do you agree with this statement. }\end{array}$} & Between Groups & 13.654 & 4 & 3.414 & 2.592 & 0.036 \\
\hline & Within Groups & 480.627 & 365 & 1.317 & & \\
\hline & Total & 494.281 & 369 & & & \\
\hline
\end{tabular}

For the question asking about tourists who violate the 14-day quarantine in Hawaii and leave their hotel room or vacation rental prior to the 14 days should be fined $\$ 5000$, there was a significant difference p.001 < 0.05 (SE.070). Baby boomers disagreed while Generation Y slightly agreed that violating the 14-day quarantine in Hawaii while leaving their hotel room or vacation rental prior to completing the 14-day quarantine, should be fined $\$ 5000$, while the other generations answered neutral.

Overall, the participants' responses appeared positive towards the measures proposed by the government of Hawaii to minimize the transmission of the coronavirus in Hawaii. The government and tourism industry in Hawaii have to take action to limit the transmission of COVID-19 until a vaccine is discovered (at the time of writing this research manuscript, the COVID-19 vaccines has not been approved by the government) or take the risk of Hawaii becoming a potential 'hot zone' for the COVID-19 virus. On the U.S. mainland, tourists can easily drive to a vacation destination while tourists to Hawaii have to consider the added cost and potential contamination of flying on an airplane to visit America's island paradise, Hawaii. Airlines need to consider the reconfiguration of the seats in its aircrafts adding dividers between seats and having fewer seats on board the flight, which can result in charging a premium price for its tickets. In addition, the majority of the respondents agreed or strongly agreed that testing for the COVID-19 should be a travel requirement prior to flying to Hawaii as an additional travel document as well as an additional COVID-19 test once arriving in Hawaii.

The participants were uncertain if the 14-day quarantine rules and fines were necessary or not. However, they realized that Hawaii quickly can become a hot zone due to all the international and mainland travelers. Since the COVID-19 pandemic, new safety measures 
need to be implemented in order to increase visitor's confidence that it is safe to travel and that airlines, hotels, and governments have to place new sanitizing and social distancing measures in order to lower the risks of transmitting COVID-19.

\section{Conclusions}

While the COVID-19 pandemic has caused the tourism industry from around the world to endure the worst recession in modern history, as an island destination, Hawaii is in a unique position to develop a balance between the needs and well-being of the local residents and the desires of the tourists, in order to produce a safe and sustainable tourist product. The coronavirus pandemic has literally stopped tourism to Hawaii, which has allowed the government and tourism officials to reset their priorities of the state in order to support more sustainable development. With the exponential growth of over 10 million tourists on an island state in the middle of the Pacific Ocean, over $5000 \mathrm{~km}$ away from the nearest major land mass, these tourists stay for longer periods of time and place added stress on the environment and the residents. As the Hawaii Tourism Authority (HTA) Resident Sentiment Survey 2019 Highlights Report, the resident sentiment towards tourism has generally weakened, meaning that there is an unequal balance of economic/social and cultural/community benefits from the tourism industry (Hawaii Tourism Authority 2019). The challenge of COVID-19 can be an opportunity for Hawaii to reset the tourism objectives and have the residents of Hawaii be included in recreating a tourism product that is sustainable for the Hawaii's residents, its culture as well as the tourism industry.

Hawaii has maintained some of the lowest number of COVID-19 cases of any major city in the United States. The results of this research study are in line with what the Governor of Hawaii mandated indicating that visitors to Hawaii can have the 14-day quarantine lifted if they produce a negative COVID-19 test within 3 days of arriving in Hawaii (Hawaii Tourism Authority 2020).

The government and tourism officials of Hawaii have an opportunity to be proactive, and introduce (as well as enforce) rules and regulations that will limit the number of COVID-19 cases in Hawaii. This can further support the local residents and improve their sentiment towards the largest employer in the state, tourism, as well as help to level the playing field for the hotels and resorts in Hawaii. As new technology enters the hospitality and tourism domain, government officials and other tourism stakeholders, including residents of the destination, all need to examine how the introduction of emerging technologies will affect the sustainability of tourism in the area. The recommendations of this study can be beneficial to a mature tourism destination, such as Hawaii, especially during the COVID-19 pandemic, and can assist Hawaii in resetting its tourism plan and regulations, in order to become more beneficial for the local residents, as well as developing a sustainable tourism product for the future, to remain competitive in the ever-growing market of tropical destinations.

Finally, this study sends an important signal to the airline industry to reconfigure its aircrafts during the COVID-19 pandemic. With fewer seats, and ensuring there are proper dividers between seats to remain a sustainable and responsible industry, along with government regulations to require the airlines industry to do so, are some measures to reduce risks. As an island destination with the vast majority of visitors traveling long haul flights to Hawaii by aircraft, it is beneficial for the state of Hawaii to encourage or even subsidize the airlines flying to Hawaii, in addition to extra precautions, such as leaving the middle seat empty, special sanitizing, and deep cleaning the aircraft cabin before each flight, as well as adding in special air filters to provide a sense of safety for tourists visiting Hawaii, as well as locals returning to Hawaii from traveling outside the state. The state of Hawaii has an opportunity to set a precedence by collaborating with the United States federal government, to put proper measures in place to limit exposer to the COVID-19 virus on all aircrafts that enters the United States. As a long-haul tourist destination, Hawaii is totally dependent on airline traffic in order to bring the 10 million tourists that visit Hawaii, which are the economic lifeblood and largest employer for the 
state economy. As the COVID-19 pandemic continues to disrupt the world's tourism market and change consumers' behavior, future research should consist of researchers, examining the implications suggested in this research paper on potential tourists to other long-haul destinations. Researchers should consider surveying potential tourists during the pandemic to island destinations where tourism is a major economic factor to the economy to ensure sustainable development. In addition, other future research should include a follow-up survey to be conducted after the pandemic, as well as three to five years after the pandemic to see if there are changes by generational cohorts.

Furthermore, the personalized attraction similarity (PAS) model may be another line of research in fusing travel recommendations among attractions, impacts, and traveler costs via digital mobile technology (Shen et al. 2016). In the PAS model, highly personalized approaches in providing access to natural attractions through real-time technology may promote sustainable approaches that limit issues of overcrowding among popular natural and built attractions.

In terms of the diversification of Hawaii's structural economy, alignment with Porter (1990) cluster approach to economic development may be a possible strategic approach to explore. The transitioning of Hawaii's economy may center on clustering other key sectors of the knowledge economy, technology, and agriculture. Advanced by Porter (2000) interconnected companies may compete, yet cooperate, to form strategic competitive advantages and stability through the diversified sectors of a regional economy. The geographic location and remoteness of Hawaii offer microeconomic advantages and disadvantages that are unique to Hawaii, along with other island destinations heavily dependent on tourism that require evolving roles of government and industry towards competitive economic development. Although clusters may be difficult to recognize in typical standard industrial classification systems, many linkages exist among collaborating industries that build competitive advantages that add to economic diversification (Porter 2000). Therefore, it would be beneficial for future research to examine cluster analysis through the nature of highly developed tourism dependent economies as an approach to economic diversification.

Author Contributions: Conceptualization, J.A. and J.L.; methodology, C.L., formal analysis, C.L. and J.M.; investigation, J.M.; writing-original draft preparation, J.A., C.L., J.M., J.L., T.H., H.I., and H.L.; writing-review and editing, J.L., J.M., C.L., and H.L. All authors have read and agreed to the published version of the manuscript.

Funding: This research received no external funding.

Institutional Review Board Statement: The study was conducted according to the guidelines of the Declaration of Helsinki, and approved by the Institutional Review Board of the University of Hawaii at Manoa (protocol code 2020-00447and approval on 21 May 2020).

Informed Consent Statement: Informed consent was obtained from all subjects involved in the study.

Data Availability Statement: The data presented in this study is not publicly available.

Acknowledgments: The researchers appreciate the Shidler Summer research grant from the Shidler College of Business at the University of Hawaii at Manoa, which has supported this research project.

Conflicts of Interest: The author declares no conflict of interest.

\section{References}

Agrusa, Jerome. 1994. Group tours in Hawaii: A survey and analysis. Annals of Tourism Research 21: 146-47. [CrossRef]

Agrusa, Jerome. 1998. Perceptions and attitudes toward the legalization of gaming in Hawaii by Japanese-speaking tourists and English-speaking tourists. Asia Pacific Journal of Tourism Research 2: 57-64. [CrossRef]

Agrusa, Jerome. 2000. Legalization of gambling in Hawaii and its potential effects on Japanese intention to visit: A philosophical inquiry. Journal of Travel Tourism Marketing 9: 211-17. [CrossRef]

Ballantyne, Roy, and Jan Packer. 2011. Using tourism free-choice learning experiences to promote environmentally sustainable behaviour: The role of post-visit 'action resources'. Environmental Education Research 17: 201-15. [CrossRef] 
Barrutia, Jose M., and Carmen Echebarria. 2015. Factors affecting the attitude of tourism-destination local authorities towards sustainable planning tools in a networking context: The Balearic Sustainability Network. Journal of Sustainable Tourism 23: 207-33. [CrossRef]

Baum, Tom, and Nguyen Thi Thanh Hai. 2020. Hospitality, tourism, human rights and the impact of COVID-19. International Journal of Contemporary Hospitality Management 32: 2397-407. [CrossRef]

Biber, Eric, Sarah E. Light, J. B. Ruhl, and James Salzman. 2017. Regulating business innovation as policy disruption: From the Model T to Airbnb. Vanderbilt Law Review 70: 1561-626.

Bimonte, Salvatore, and Antonella D'Agostino. 2020. Tourism development and residents' well-being: Comparing two seaside destinations in Italy. Tourism Economics: The Business and Finance of Tourism and Recreation. [CrossRef]

Blair, Allyson. 2018. Hawaii Sues for Info on Airbnb Owners Who Aren't Paying Taxes. Available online: http:/ / www.hawaiinewsnow. com/story/39043083/hawaii-heads-to-court-to-get-info-on-airbnb-owners-who-arent-paying-taxes/ (accessed on 9 May 2020).

Brunt, Paul, Susan Horner, and Semley Natalie. 2017. Research Methods in Tourism, Hospitality and Events Management. London: Sage.

Buckley, Ralf, and Diane Westaway. 2020. Mental health rescue effects of women's outdoor tourism: A role in COVID-19 recovery. Annals of Tourism Research 85: 103041. [CrossRef]

Department of Business, and Economic Development and Tourism. 2018. Labor Force and Jobs; Honolulu: Department of Business, Economic Development \& Tourism.

Edwards, Peter. 2009. Sustainable financing for ocean and coastal management in Jamaica: The potential for revenues from tourist user fees. Marine Policy 33: 376-85. [CrossRef]

Faulkner, Bill, and Svetlana Vikulov. 2001. Katherine, washed out one day, back on track the next: A post-mortem of a tourism disaster. Tourism Management 22: 331-44. [CrossRef]

Geminiani, Victor, and Madison DeLuca. 2018. Hawaii Vacation Rentals: Impact on Housing and Hawaii's Economy. Honolulu: Hawaii Appleseed Center for Law and Economic Justice.

Guttentag, Daniel. 2015. Airbnb: Disruptive innovation and the rise of an informal tourism accommodation sector. Current Issues in Tourism 18: 1192-217. [CrossRef]

Hajibaba, Hom, and Sara Dolnicar. 2017. Substitutable by peer-to-peer accommodation networks? Annals of Tourism Research 66: 185-88. [CrossRef]

Harris, John. 2018. Profiteers Making a Killing on Airbnb and Erode Communities. Available online: https:/ /www.theguardian.com/ commentisfree/2018/feb/12/profiteers-killing-airbnb-erode-communities (accessed on 19 April 2019).

Hawaii Tourism Authority. 2017. Air Visitor Spending 2017 YTD. Honolulu: Hawaii Tourism Authority. Available online: www. hawaiitourismauthority.org/research/annual-visitor-research-reports (accessed on 9 March 2020).

Hawaii Tourism Authority. 2018. 2018 Visitor Satisfaction and Activity Report. Available online: https:/ /www.hawaiitourismauthority. org/media/4210/vsat_2018_annual_report_v7-final-ada-compliant.pdf (accessed on 19 January 2020).

Hawaii Tourism Authority. 2019. 2019 Annual Visitor Research Report. Available online: https://files.hawaii.gov/dbedt/visitor/ visitor-research/2019-annual-visitor.pdf (accessed on 4 March 2020).

Hawaii Tourism Authority. 2020. COVID-19 Update. Available online: https://www.hawaiitourismauthority.org/media/4333 / coronavirus-impact-update-033020.pdf (accessed on 4 February 2020).

Herremans, Irene. 2006. Cases in Sustainable Tourism Resource Guides for an Experiential-Learning Environment (Hospitality, Travel and Tourism). New York: Haworth Hospitality Press.

Jang, Shawn, and Liping Cai. 2002. Travel motivations and destination choice: A study of British outbound market. Journal of Travel and Tourism Marketing 13: 111-32. [CrossRef]

Jang, Soo Cheong (Shawn), Alastair Morrison, and Joseph T. O'leary. 2004. A procedure for target market selection in tourism. Journal of Travel and Tourism Marketing 16: 19-33. [CrossRef]

Kim, Min-Seong, Brijesh Thapa, and Hany Kim. 2017. International tourists' perceived sustainability of Jeju Island, South Korea. Sustainability 10: 73. [CrossRef]

Kim, Samuel Seongseop, Choong-Ki Lee, and David B. Klenosky. 2003. The influence of push and pull factors at Korean National Parks. Tourism Management 24: 169-80. [CrossRef]

Kim, Samuel Seongseop, and Bruce Prideaux. 2005. Marketing implications arising from a comparative study of international pleasure tourist motivations and other travel-related characteristics of visitors to Korea. Tourism Management 26: 347-57. [CrossRef]

Kitchenham, Barbara. 2004. Procedures for Performing Systematic Reviews. Technical Report. Keele: Keele University, vol. 33, pp. 1-26.

Kozak, Metin. 2002. Comparative analysis of tourist motivations by nationality and destinations. Tourism Management 23: 221-32. [CrossRef]

Langley, Paul, and Andrew Leyshon. 2017. Platform capitalism: The intermediation and capitalization of digital economic circulation. Finance and Society 3: 11-31. [CrossRef]

Lee, Kyuho, and Zhao Jinlin. 2003. Japanese travellers' service preferences in U.S. Hotels. Journal of Travel and Tourism Marketing 14: 67-85. [CrossRef]

Lema, Joseph, Jerome Agrusa, and Dorina Buda. 2010. The process of experiential learning: Implications for dark tourism. Buletinul Universităţii Naţionale de Apărare "Carol I" XX: 440-47.

Linnes, Cathrine, Paul Kowalski, Joseph Lema, Wendy Lam, and Jerome Agrusa. 2014. Social media and technology: The influence on Hawaii hotels. The Consortium Journal of Hospitality and Tourism Management 19: 54-73. 
Loria, Kevin, and Samantha Lee. 2018. Here's Which Generation You're Part of Based on Your Birth Year-and Why Those Distinctions Exist. Business Insider. Available online: https:/ / www.businessinsider.com/generation-you-are-in-by-birth-year-millennial-genx-baby-boomer-2018-3 (accessed on 9 July 2020).

Min, Jihye, Birendra KC, Seungman Kim, and Jaehoon Lee. 2020a. The Impact of Disasters on a Heritage Tourist Destination: A Case Study of Nepal Earthquakes. Sustainability 12: 6115. [CrossRef]

Min, Jihye, Jerome Agrusa, Joseph Lema, and Harold Lee. 2020b. The Tourism Sector and U.S. Regional Macroeconomic Stability: A Network Approach. Sustainability 12: 7543. [CrossRef]

McCartney, Glenn. 2020. The impact of the coronavirus outbreak on Macao. From tourism lockdown to tourism recovery. Current Issues in Tourism, 1-10. [CrossRef]

McKercher, Bob, and Donna Y. Y. Wong. 2004. Understanding tourism behaviour: Examining the combined effects of prior visitation history and destination Status. Journal of Travel Research 43: 171-79. [CrossRef]

Mistilis, Nina, and Pauline Sheldon. 2005. Knowledge management for tourism crises and disasters. Tourism Review International 10: 39-46. [CrossRef]

Molnar, Andras. 2019. SMARTRIQS: A simple method allowing real-time respondent interaction in Qualtrics surveys. Journal of Behavioral and Experimental Finance 22: 161-69. [CrossRef]

Morrison, Alastair M., and Joseph T. O'Leary. 1994. Segmenting travel markets with the international tourism role (ITR) scale. Journal of Travel Research 33: 24-31.

Park, Joungkoo, Gary D. Ellis, Samuel Seongseop Kim, Edward J. Ruddell, and Jerome Agrusa. 2006. Predictor of social equity and price acceptability: Judgments of user fees. Journal of Travel and Tourism Marketing 21: 89-104. [CrossRef]

Porter, Michael. 1990. The Competitive Advantage of Nations. New York: Free Press.

Porter, Michael. 2000. Location, competition, and economic development: Local clusters in a global economy. Economic Development Quarterly 14: 15-34. [CrossRef]

Qiu, Richard T. R., Jinah Park, ShiNa Li, and Haiyan Song. 2020. Social costs of tourism during the COVID-19 pandemic. Annals of Tourism Research 84: 102994. [CrossRef] [PubMed]

Qualtrics. 2020. Available online: https:/ / en.wikipedia.org/wiki/ (accessed on 30 June 2020).

Reisinger, Yvette, and Lindsay W. Turner. 2002. Cultural differences between Asian tourist markets and Australian hosts: Part 2. Journal of Travel Research 40: 385-95. [CrossRef]

Reynisdottir, Maria, Haiyan Song, and Agrusa Jerome. 2008. Willingness to pay entrance fees to natural attractions in Iceland. Tourism Management 29: 1076-83. [CrossRef]

Ritchie, Brent R. 2004. Chaos, crises and disasters: A strategic approach to crisis management in the tourism industry. Tourism Management 25: 669-83. [CrossRef]

Rittichainuwat, Bongkosh N. 2013. Tourists' and tourism suppliers' perceptions towards crisis management on tsunami. Tourism Management 34: 112-21. [CrossRef]

Rittichainuwat, Bongkosh N., Robert Nelson, and Rahmafitria Fitri. 2018. Applying the perceived probability of risk and bias toward optimism: Implications for travel decisions in the face of natural disasters. Tourism Management 66: 221-32. [CrossRef]

Rosenbaum, Mark Scott, and Daniel L. Spears. 2005. Who buys that? Who does that? Analysis of cross-cultural consumption behaviors among tourists in Hawaii. Journal of Vacation Marketing 11: 235-47. [CrossRef]

Shen, Junge, Deng Cheng, and Gao Xinbo. 2016. Attraction recommendation: Towards personalized tourism via collective intelligence. Neurocomputing 173: 789-98. [CrossRef]

Shoemaker, Stowe. 1994. Segmenting the U.S. travel market according to benefits realized. Journal of Travel Research 32: 8-21. [CrossRef]

Tanner, Carmen, Florian G. Kaiser, and Sybille WÓfing Kast. 2004. Contextual conditions of ecological consumerism: A food-purchasing survey. Environment and Behavior 36: 94-111. [CrossRef]

Taylor, Mia. 2019. Plotting a Sustainable Path Forward for Hawaii's Tourism Industry. Available online: https://www.travelpulse. $\mathrm{com} /$ news / .../plotting-a-sustainable-path-forward-for-hawaiis-t (accessed on 1 June 2019).

UHERO. 2019. Charting a New Course for Hawaii's Tourism. Available online: https://www.uhero.hawaii.edu/products/view/616 (accessed on 3 June 2019).

UNWTO. 2020. Impact Assessment of the COVID-19 Outbreak on International Tourism. Madrid: United Nations World Tourism Organization, Available online: https:/ / www.unwto.org/impact-assessment-of-thecovid-19-outbreak-on-international-tourism (accessed on 4 January 2021).

Wilson, Reid. 2017. Hawaii's \$14 Billion Tourism Industry back to Pre-Recession Levels. The Washington Post. Available online: https:/ /www.washingtonpost.com/blogs/govbeat/wp/2013/09/27/hawaiis-14-billion-tourism-industry-back-toprerecessionlevels / ?noredirect=on\&utm_term $=.543 \mathrm{f} 45 \mathrm{fe} 9 \mathrm{~b} 82$ (accessed on 3 March 2020).

Woody, Todd. 2015. Food Independence Could be a Matter of Survival for the U.S. Most Isolated State. Available online: http: //www.takepart.com/article/2015/06/29/hawaii-local-food (accessed on 14 May 2020). 